\title{
Effects of Three Drying Techniques on Mineral Composition of Some Leafy Garden Vegetables
}

\author{
Muhammad Gidado Liman ${ }^{1}$, Abubakar Sadiq Abdullahi ${ }^{2}$, Abdul'azeez Lawal \\ Maigoro ${ }^{1}$ and Kabiru Jega Umar ${ }^{1}$ \\ ${ }^{1}$ (Department of Pure \& Applied Chemistry, Usmanu Danfodiyo University, Sokoto, Nigeria) \\ 2(Agricultural and Bioresource Engineering Programme, Abubakar Tafawa Balewa University, Bauchi,
}

Nigeria)

\begin{abstract}
The effect of three different drying techniques (Sun drying at ambient temperature for 4 days, oven drying at $150{ }^{\circ} \mathrm{C}$ for 4 hours, and drying with electrical moisture analyzer stabilized at $70{ }^{\circ} \mathrm{C}$ for 1 day) on the mineral composition (i.e. $\mathrm{Ca}, \mathrm{K}, \mathrm{Mg}, \mathrm{Na}$, and $\mathrm{P}$ ) of three different green leafy vegetables (Moringa oleifera, Spinacea oleraceae and Vernonia amygdalina) were studied. The results obtained showed that the different types of vegetables had an appreciable amount of minerals, though with varying concentration. The Spinach, Spinacea oleraceae samples' ability to retain the studied nutrients was much favored by sun drying technique. Its content for $\mathrm{P}, \mathrm{K}, \mathrm{Na}, \mathrm{Ca}$ and $\mathrm{Mg}(4.47 \mathrm{mg} / \mathrm{kg}, 18.41 \mathrm{mg} / 100 \mathrm{~g}, 21.00 \mathrm{mg} / 100 \mathrm{~g}, 0.19 \%, 0.35 \%)$ are probably the best result for it. As for the Drumstick, Moringa oleifera, its ability to retain the investigated nutrients is enhanced by the moisture analyzer drying method. Its content for $\mathrm{P}, \mathrm{K}, \mathrm{Na}, \mathrm{Ca}$ and $\mathrm{Mg}(4.03 \mathrm{mg} / \mathrm{kg}, 7.83$ $\mathrm{mg} / 100 \mathrm{~g}, 20.33 \mathrm{mg} / 100 \mathrm{~g}, 0.11 \%, 0.16 \%$ ) are likely the best for it. The Bitter leaf, Vernonia amygdalina seems to be much favored, in its nutrients retention ability by using oven drying. This could be seen from the content of P, K, Na, Ca and Mg (4.04 mg/kg, $20.58 \mathrm{mg} / 100 \mathrm{~g}, 12.08 \mathrm{mg} / 100 \mathrm{~g}, 0.07 \%, 0.14 \%)$ obtained. However, no definite conclusion could be drawn as which method is the best for each of the investigated vegetables in relation to all the studied elements.
\end{abstract}

Keywords: Drying Techniques, Leafy Vegetables, Moringa oleifera, , Sokoto, Spinacea oleraceae, Vernonia amygdalina

\section{INTRODUCTION}

The fresh edible portions of herbaceous plant which traditional African societies have always exploited are the vegetables, they are considered as natural gift given by the Almighty God to human beings, as a source of nutrient, food security and income generation.

Vegetables, at all times are known to be in form of edible roots, stems, leaves, flowers, fruits and of course through seeds which are known to be inexpensive but contain valuable amount of food ingredients which can be successfully utilized to build up and repair the body, maintain alkalinity of the body reserve due to their composition of mineral elements, vitamins, proteins, carbohydrates, fibers and some certain hormones precursors to the diet [1].

The three leafy vegetables considered in this work are very common and widely used in the study area (Sokoto). However, the effort to ascertain the effect of the methods of drying these leafy vegetables was borne out of the migration of using the vegetables in their fresh form to the use of the vegetables in their dry form probably due to their scarcity or absence in the dry season. This is why we saw the need to analyze the mineral contents of these leafy vegetables after being subjected to various drying techniques. The result of which could be used to advised on the best drying method which can guarantee the retention of the mineral contents. This idea is in conformity with the objectives and findings of some other Researchers.

The minerals which are the naturally occurring inorganic elements constitute only a small amounts proportion of nutrients with definite chemical compositions; the vegetables are the excellent source of minerals that contributes to the recommended dietary allowances of the essential nutrients required for normal metabolic activities of the body tissues [2].

Robert [3], reported that; vegetables are good source of testing and attractive-looking part of our daily meals, which are an important source of vitamins and minerals, thus provides bulk, which aids in digestion.

Vegetables are perishable products with high moisture content which ranges between $60.0-98.8 \%$ [1]. Therefore there is need for its conservation. In Nigeria today we are bedeviled by constant power failure, which make refrigeration of these products difficult, hence there is the need to explore an alternative way for preserving them. This study therefore examine the effects of three drying methods/techniques on some selected minerals composition of some three commonly consumed vegetables in the Sokoto region of Nigeria and to the awareness of the mass of nutrients they take during ingestion of vegetables. The finding will also be useful for 
the populace and nutritionist in choosing the most preferable methods of drying (preserving their vegetables) [1].

\subsection{Materials}

\section{METHODOLOGY}

The apparatus, instrument and chemicals used in the conduct of this research are the routine laboratory apparatus, instrument and chemicals. However, where special apparatus, instrument and chemicals are used, it will be stated.

\subsubsection{Sampling}

Notably three vegetables samples were used for this analysis and these leaves were purchased freshly from the garden close to student hostel, UDUS, permanent site (Sokoto, Sokoto state, Nigeria located on $13.0833^{\circ} \mathrm{N}, 5.2500^{\circ} \mathrm{E}$ ); and divided into nine parts and each part is labeled with regards to the leaves samples and the mode of drying it is to be subjected to. In labeling the samples, the first letter (upper case) represents the leaves type while the second letter (lower case) represents the drying technique employed. Thus, the spinach leaves associated with sun drying are labeled with 'Ss' and the Drumstick leaves sample associated with oven drying is labeled 'Do' while the bitter leaves sample associated with moisture dryer is labeled 'Bm'.

\subsubsection{Sample Treatment}

After the sampling, the samples leaves were cleaned with water, destalked, separated and were appropriately labeled and kept for the analyses.

\subsection{Methods}

The methods employed for the analyses are listed below.

\subsubsection{Determination of Moisture Content}

Moisture often refers to as the water content, present in sample vegetable. The proportion of water in tissues is very variable; but is higher in natural products and as such is useful to control the water content of foods while processing or investigation. Procedure below shows how such process can be endured:-

The leaves to be analyzed were collected after sample and are put on empty dishes and measured under a weighed using a balance. The weight is noted as $\mathrm{W}_{0}$. The porcelain dishes with the specimens (leaves) were weighed on a balance and noted as $\mathrm{W}_{1}$

The weighed samples are placed into a moisture analyzer heater thermosets at $70^{\circ} \mathrm{c}$ for $24 \mathrm{hrs}$. The dried samples were cooled for about 20 - 30mins under controlled conditions (ATP).

The cooled dried samples were then weighed on a balance and noted with label $\mathrm{W}_{2}$. After both the readings and the procedures were taken then calculation for the average moisture content was done later using the formula below:

For sample before drying $=$ weight of empty dish $(\mathrm{Wo})+$ weight of fresh sample $\left(\mathrm{W}_{1}\right)$.

Sample after drying $=$ weight of empty dish $(\mathrm{Wo})+$ weight of dried sample $\left(\mathrm{W}_{2}\right)$.

Average moisture content $\%=$ sample before drying - sample after drying

\subsubsection{Determination of Ash Content} proved below:

Readily dried sample analysis cannot be triumphed unless samples are grounded and ashed as can be

The dried samples are grinded into powdered with reference to each leaf and so $2 \mathrm{~g}$ of the grinded samples were taken and weighed in a clean porcelain crucible and weighed as Xo and then weighed with the dried sample and labeled as $\mathrm{X}_{1}$.

The weighed samples are then placed into a Lenton electric furnace at $500^{\circ} \mathrm{c}$ for $3 \mathrm{hrs}$. The ashed sample was cooled in a desiccators and the cooled dried sample was then weighed and labeled $\mathrm{X}_{2}$.

The result and the procedure were recorded and calculated for average ash content.

\subsubsection{Drying Methods}

The drying methods considered in this research work are:

\subsubsection{Sun Drying}

This is the old fashioned methods/way to dry foods because it uses the sun and the natural movement of air, and so the following procedure was used for this [4].

Procedure

The labeled leaves sample are sprayed in a wooden tray under the sun and allowed to dry for five days. 
The dried leaves are then collected, smashed and grinded to powder.

The ground leaves samples are labeled as 's' and ashed in the Asher for further analysis.

\subsubsection{Moisture Analyzer Drying}

Besides sun drying; the safer and most guaranteed method of drying is the moisture dryer, because here only the moisture is removed and foods sample are less subjected to bacterial and fungal attack ; thus the heater provides automatically controlled heat and ventilation and serves as the simplest as proceed below [4]. Procedure

The samples leaves are arranged on a metal racket trays of the dryer, controlled at temperature of $35^{\circ} \mathrm{c}$ for one day (i.e. 24hrs).

The samples are then collected and ground into powder in a mortar and ashed into ashes and stored in a polythene bag and then labeled as ' $m$ '.

\subsubsection{Oven Drying}

It is the simplest way of drying food because neither hard procedure is required nor any special equipment is needed [4].

Procedure

The sample leaves were cleaned, destalked and then subjected to dryness in an oven on a tray rack.

The temperature is set and controlled to exactly $150^{\circ} \mathrm{c}$ and then closed and switched ON.

The labeled leaves samples are allowed to dry in the oven for $4 \mathrm{hrs}$.and then switched OFF.

The dried samples are then allowed to cooled for about an hour before grinding them to powder and then ashed to ashes for further analysis. The ashes obtained are packed in a polythene bag and label as 'o'

\subsubsection{Mineral Analysis}

This involves two steps which are penultimate in this analysis these steps are:-

- $\quad$ Digestion of the labeled ashes \{Aliquot formation.(dry procedure)\}

- Mineral determination.

\subsubsection{Digestion of the Labeled Ashes (Dry Procedure)}

Dry ashing is suitable for the determination of both heavy and light metals in plants tissues and may be also applicable to the determination of other elements as well. But precisely here we use it in the determination of mineral elements in plant leaves such as $\mathrm{Ca} ; \mathrm{Mg} ; \mathrm{K} ; \mathrm{Na} ; \& \mathrm{P}$.

\subsubsection{Mineral Determination}

In this section three basic methods were used for the identification of these five elements ( $\mathrm{Ca} ; \mathrm{Mg} ; \mathrm{Na} ; \mathrm{K}$; \& P.) these are:-

- The Flame photometer (where potassium and sodium were found)

- $\quad$ The EDTA titration method (where calcium and magnesium were found)

- $\quad$ The Spectrophotometer (in which phosphorus was determined).

\subsection{Results}

\section{RESULTS AND DISCUSSION}

The result of minerals composition of the three different drying techniques [i.e. sun drying at ambient temperature; oven drying at $150^{\circ} \mathrm{C}$ in $4 \mathrm{hrs}$ and moisture analyzer heater at $70^{\circ} \mathrm{C}$ for $4 \mathrm{hrs}$.] on green leaves of spinach; drumstick; and bitter leaf are given in Table, $3.1-3.3$

Table 3.1: Mineral Composition of Sun Dried Leaves of Spinach; Drumstick and Bitter Leaf

\begin{tabular}{llllll}
\hline Samples & $\mathrm{P}(\mathrm{mg} / \mathrm{kg})$ & $\mathrm{K}(\mathrm{mg} / 100 \mathrm{~g})$ & $\mathrm{Na}(\mathrm{mg} / 100 \mathrm{~g})$ & $\mathrm{Ca}(\%)$ & $\mathrm{Mg}(\%)$ \\
Spinach & $4.4728 \pm 0.05$ & $18.4175 \pm 3.82$ & $21.0000 \pm 2.5$ & $0.1850 \pm 0.01$ & $0.3485 \pm 0.01$ \\
Drumstick & $3.8202 \pm 0.01$ & $3.8333 \pm 3.81$ & $20.668 \pm 3.9$ & $0.1115 \pm 0.01$ & $0.1485 \pm 0.02$ \\
Bitter leaf & $3.3730 \pm 0.01$ & $20.0833 \pm 3.81$ & $13.2500 \pm 0.01$ & $0.0750 \pm 0.01$ & $0.1267 \pm 0.01$ \\
\hline
\end{tabular}




\section{Effect of Three Drying Techniques on Mineral Composition of Some Leafy Garden Vegetables}

Table 3.2: Mineral Composition of Moisture Analyzer Dried Leaves of Drumstick, Spinach and Bitter Leaf

\begin{tabular}{llllll}
\hline Sample & $\mathrm{P}(\mathrm{mg} / \mathrm{kg})$ & $\mathrm{K}(\mathrm{mg} / 100 \mathrm{~g})$ & $\mathrm{Na}(\mathrm{mg} / 100 \mathrm{~g})$ & $\mathrm{Ca}(\%)$ & $\mathrm{Mg}(\%)$ \\
Spinach & $3.9516 \pm 0.03$ & $18.1667 \pm 2.83$ & $17.7500 \pm 4.33$ & $0.1433 \pm 0.01$ & $0.2450 \pm 0.01$ \\
Drumstick & $4.0337 \pm 0.33$ & $7.8333 \pm 2.88$ & $20.3333 \pm 3.8$ & $0.1084 \pm 0.01$ & $0.1567 \pm 0.01$ \\
Bitter leaf & $3.6685 \pm 0.00$ & $18.9167 \pm 2.60$ & $12.0830 \pm 2.9$ & $0.0650 \pm 0.01$ & $0.1150 \pm .01$ \\
\hline
\end{tabular}

Table 3.3: Mineral Constituents in Oven Dried Sample of Spinach, Drumstick and Bitter Leaf

\begin{tabular}{llllll}
\hline Sample & $\mathrm{P}(\mathrm{mg} / \mathrm{kg})$ & $\mathrm{K}(\mathrm{mg} / 100 \mathrm{~g})$ & $\mathrm{Na}(\mathrm{mg} / 100 \mathrm{~g})$ & $\mathrm{Ca}(\%)$ & $\mathrm{Mg}(\%)$ \\
Spinach & $3.9997 \pm 0.02$ & $13.0833 \pm 2.88$ & $17.9180 \pm 5.2$ & $0.1800 \pm 0.01$ & $0.2184 \pm 0.01$ \\
Drumstick & $4.4197 \pm 0.02$ & $8.5000 \pm 2.50$ & $18.667 \pm 3.8$ & $0.1467 \pm 0.01$ & $0.0967 \pm 0.01$ \\
Bitter leaf & $4.0378 \pm 0.02$ & $20.5833 \pm 3.81$ & $12.083 \pm 1.4$ & $0.0734 \pm 0.01$ & $0.1383 \pm 0.04$ \\
\hline
\end{tabular}

\subsection{Discussion}

The amount of calcium content in Sun dried sample shows that Spinach has the highest value with $0.19 \%$ followed by Drumstick with $0.11 \%$ and then the bitter leaf with $0.08 \%$ which follows the sequence of Spinach > Drumstick > Bitter leaf. Likewise in the moisture analyzer drying method the same result is seen as in the sun drying but the values varies in the form of spinach with $0.14 \%$; Drumstick with $0.11 \%$; and then the bitter leaf with $0.07 \%$ in the sequence similar with that of sun dry (Spinach > Drumstick > Bitter leaf). Also the oven dried sample follows this route as seen in Spinach with $0.18 \%$ then Drumstick with $0.15 \%$ and the Bitter leaf with $0.07 \%$ in the same pattern with greater heights. And this might have arisen due to the countless instances of life saving nutrition's attributed to it [5].

Likely magnesium was determined using the EDTA titration method in which the range of finding varies not as that seen in calcium: in sun dried sample Spinach carries the highest values with $0.35 \%$ followed by Drumstick with $0.15 \%$ then the Bitter leaf with $0.13 \%$ in the sequence: Spinach > Drumstick > Bitter leaf. Also in the moisture analyzer drying the result follows the sequence: Spinach > Drumstick > Bitter leaf $(0.25 \%$ for Spinach; $0.16 \%$ for Drumstick and then $0.11 \%$ for Bitter leaf). But in oven dried samples the sequence changes with a less primitive value than the other methods even though for Spinach the value is less that obtained in Moisture analyzer. For Spinach it was $0.22 \%$ followed by Bitter leaf with $0.14 \%$ then the Drumstick with $0.10 \%$ (in the sequence: Spinach > Bitter leaf > Drumstick). Probably this might be due to the heating effect of the drying minerals which do escape/vaporize and as such lesser values in $\mathrm{Mg}$ is seen.

Potassium content was determined by the use of flame photometer where by the values found in sun dried samples $(18.42 \mathrm{mg} / 100 \mathrm{~g})$ is greater than that seen in moisture analyzer drying $(18.17 \mathrm{mg} / 100 \mathrm{~g})$ and also greater than that in Oven drying $(13.00 \mathrm{mg} / 100 \mathrm{~g})$ for Spinach (spinacea oleracea). Same is observed for Drumstick; the values found in sun dried $(8.83 \mathrm{mg} / 100 \mathrm{~g})$ samples is greater than that seen in Oven dried sample $(8.50 \mathrm{mg} / 100 \mathrm{~g})$ and also greater than that seen in moisture analyzer $(7.83 \mathrm{mg} / 100 \mathrm{~g})$. As for Bitter leaf (vernonia amygdalina), great content is found in Oven dried sample with $20.58 \mathrm{mg} / 100 \mathrm{~g}$ followed by that for sun dried sample with $20.08 \mathrm{mg} / 100 \mathrm{~g}$ then the least is seen for moisture analyzer with $18.92 \mathrm{mg} / 100 \mathrm{~g}$. This observation may probably be due to $\mathrm{K}$ being cationic element that does not polarizes easily in heating but forms oxides when exposed to light and air.

Sodium like potassium was also found/determined by titration with EDTA in which Drumstick has the highest value for all the three methods used for drying followed by spinach and then the Bitter leaf; the sequence and order in which they appear is Drumstick $>$ Spinach $>$ Bitter leaf. The values obtained for sun drying showed that, Spinach has $2.10 \mathrm{mg} / 100 \mathrm{~g}$ followed by Drumstick with $2.07 \mathrm{mg} / 100 \mathrm{~g}$ then Bitter leaf with $1.33 \mathrm{mg} / 100 \mathrm{~g}$ (Spinach > Drumstick > Bitter leaf). Likewise for moisture analyzer, Drumstick got $2.03 \mathrm{mg} / 100 \mathrm{~g}$, Spinach got $1.78 \mathrm{mg} / 100 \mathrm{~g}$ while Bitter leaf got $1.21 \mathrm{mg} / 100 \mathrm{~g}$ as the least (Drumstick > Spinach > Bitter leaf). The Oven drying method followed the same sequence, with values of $1.87 \mathrm{mg} / 100 \mathrm{~g}$ for Drumstick; Spinach gave 1.79 $\mathrm{mg} / 100 \mathrm{~g}$ then Bitter leaf shows with $1.21 \mathrm{mg} / 100 \mathrm{~g}$.

The Phosphorus, $\mathrm{P}$ was determined using the spectrophotometer. The result shows a trend similar to that seen in the other elements and more closely with that seen for sodium, Na. The Sun drying technique reveals that Spinach has $4.47 \mathrm{mg} / \mathrm{kg}$, followed by the Drumstick with $3.82 \mathrm{mg} / \mathrm{kg}$ and then the Bitter leaf with $3.37 \mathrm{mg} / \mathrm{kg}$. In using moisture analyzer Drumstick yielded $4.04 \mathrm{mg} / \mathrm{kg}$, the Spinach has $3.95 \mathrm{mg} / \mathrm{kg}$ and then the bitter leaf with $3.37 \mathrm{mg} / \mathrm{kg}$. For the Oven drying technique, it has same trend with the moisture analyzer method: Drumstick (4.42 mg/kg), Bitter leaf $(4.04 \mathrm{mg} / \mathrm{kg})$ and Spinach $(4.00 \mathrm{mg} / \mathrm{kg})$. What was observed might be as a result of the ability of the Drumstick to save nutrient for a long time and to the spinach's strong ability to absorb almost everything that comes its way.

The findings of this research are in close agreements with many findings such as Aletor and Abiodun [6], Satwase et. al [7], Asaolu et. al. [8], Kiremere et. al. [9], Oladele and Aborisade [10], Tesleem et. al. [11], Idowu [1], N.R.C [12] and Martha [13]. 


\section{CONCLUSION:}

From the results obtained in this research it is clearly seen that, there is no definite pattern followed by all the samples considered in their retention of different elements when subjected to different drying methods. But, the Spinach, Spinacea oleraceae samples' has the ability to retain the studied nutrients very much by sun drying technique. Its content for $\mathrm{P}, \mathrm{K}, \mathrm{Na}, \mathrm{Ca}$ and $\mathrm{Mg}(4.47 \mathrm{mg} / \mathrm{kg}, 18.41 \mathrm{mg} / 100 \mathrm{~g}, 21.00 \mathrm{mg} / 100 \mathrm{~g}, 0.19 \%$, $0.35 \%)$ are probably the best result for it. Whereas, the Drumstick, Moringa oleifera, has better ability to retain the investigated nutrients by the method of moisture analyzer. Its content for P, K, Na, Ca and $\mathrm{Mg}(4.03 \mathrm{mg} / \mathrm{kg}$, $7.83 \mathrm{mg} / 100 \mathrm{~g}, 20.33 \mathrm{mg} / 100 \mathrm{~g}, 0.11 \%, 0.16 \%$ ) are likely the best for it. The Bitter leaf, Vernonia amygdalina, also seems to be much favored, in its nutrients retention ability by using oven drying. This could be seen from the content of $\mathrm{P}, \mathrm{K}, \mathrm{Na}, \mathrm{Ca}$ and $\mathrm{Mg}(4.04 \mathrm{mg} / \mathrm{kg}, 20.58 \mathrm{mg} / 100 \mathrm{~g}, 12.08 \mathrm{mg} / 100 \mathrm{~g}, 0.07 \%, 0.14 \%)$ obtained. However, no definite conclusion could be drawn as which method is the best for each of the investigated vegetables in relation to all the studied elements. Further studies is recommended to uncover the reason(s) behind non definite approach to nutrients' retention, probably by carrying in-depth research.

\section{References}

[1]. O., Idowu, Effects of Drying Technique on some Vegetable Leaves, Journal of Science and Technology, University of Lagos. Nigeria 2(2), 2008, 80-81.

[2]. I. E., Akubugwo, A. N. B., Obasi and S. C., Ginika. (2007), Nutritive value of S. nigram seed and leaves Journal of nutrition, 6(4), 2007, 323-326.

[3]. B., Robert, The new Book of Popular Science by Grolier in Cooperated, U.S.A., 4(4), 1981, 145-148. .

[4]. K., Mary, Drying Foods: A circular of Cooperative Extension Service University of Illinoise at Urbana Champaign College of Agriculture; 1994, 1227.

[5]. J. A., Duke, (1983), The handbook of Energy Crops; (Unpublished). Retrieved from: http://www.hortpurdue.edu/new\%20crop/dukeenergy/moringa_oleifera.html.\% 20on\%206/8/2009

[6]. O., Aletor and A. R., Abiodun, Assessing the Effects of Drying on the Functional Properties and Protein Solubility of some Edible Tropical Leafy Vegetables, Research Journal of Chemical Sciences, 3(2), 2013, 20-26.

[7]. A. N., Satwase, G. R., Pandhre, PG., Sirsat and YR., Wade, Studies on Drying Characteristic and Nutritional Composition of Drumstick Leaves by Using Sun, Shadow, Cabinet and Oven Drying Methods, Open Access Scientific Reports, 2(1), 2013,1 -4.

[8]. S. S., Asaolu, O. S., Adefemi,, I. G., Oyakilome, K. E., Ajibulu and M. F., Asaolu. Proximate and Mineral Composition of Nigerian Leafy Vegetables, Journal of Food Research, 1(3), 2012, $214-218$.

[9]. B. T., Kiremere, E., Musinguzi, J. K., Kikafunda.and F. B., Lukwago, African Journal of Food Agriculture, Nutrition and Development, 10(5), 2010, $2587-2600$.

[10]. O. O., Oladele and A. T., Aborisade, Influence of Different Drying Methods and Storage on the Quality of Indian Spinach (Basella rubra I.), American Journal of Food Technology, 4(2), 2009, 66 - 70.

[11]. I., Tesleem, A., Folusho,O., Gani and M.,Rasak, Mineral and Phytochemical Content In Leaves of Talinum triagulare (Water Leaf) Subjected to Different Processing Methods, The Internet Journal of Nutrition and Wellness, 7(2), 2008,

[12]. National Research Council, Moringa lost crop of Africa (National Academic Press; Ibadan, Nigeria, 2006)

[13]. V., Martha. Retrieved from: .http://www.harbszoo200.com/herbs/herbs_bitter_leaf.htm retrieved on 6/01/2009, 2000.. 